$\mathrm{J}$ uż od pierwszych stron tego wydawnictwa wyczuwa się wysmakowany gust jego autorów i redaktorki Jagny Urbańskiej. Aby bowiem nadać mu charakter nawiązujący do tradycji dawnej książki, zastosowali oni szereg estetyzujących zabiegów, jak całostronicowe, fotograficzne imitacje kart papieru żeberkowego oraz zestawienie inkunabułowych inicjałów ze współczesnym napisem na okładce i stronie tytułowej. 0 wizualnej atrakcyjności opracowania przesądza jednak jego szata edytorska, która została oparta na koncepcji jednokolumnowego tekstu o zgrabnym foncie, klasycznych proporcjach marginesów oraz historyzujących inicjałach w renesansowym guście.

Koncepcja ta znakomicie współgra z założeniem treściowym książki, którym jest prezentacja wszystkich (tj. osiemnastu) woluminów inkunabułowych oraz wyselekcjonowanych „ze względu na treść lub formę zewnętrzną"1 dziewięćdziesięciu czterech spośród dwustu osiemdziesięciu czterech książek XVI-wiecznych ze zbiorów Biblioteki Uniwersytetu Kazimierza Wielkiego w Bydgoszczy. We wstępie do publikacji czytelnik zostaje poinformowany o konstrukcji omówień poszczególnych dzieł. Składają się one

${ }^{1}$ H. Dubowik, Inkunabuły i cimelia z XVI wieku $w$ zbiorach Biblioteki Uniwersytetu Kazimierza Wielkiego w Bydgoszczy, przy współpracy A. Chlewickiej i B. Iwańskiej-Cieślik, Bydgoszcz 2009, s. 8.

\section{Henryk Dubowik, Inkunabuły i cimelia z XVI wieku w zbiorach Biblioteki Uniwersytetu Kazimierza Wielkiego w Bydgoszczy, przy współpracy Aldony Chlewickiej i Bernardety Iwańskiej-Cieślik, Bydgoszcz: Wydawnictwo Uniwersytetu Kazimierza Wielkiego 2009, 190 s., il. barwne, ISBN 978-83-7096-722-2}

przede wszystkim z opisu katalogowego, który przywołuje odpowiednie pozycje bibliograficzne i rozwija skróty dla łatwości lektury. Rok wydania jest podany cyframi arabskimi, natomiast paginacja i foliacja zgodnie $\mathrm{z}$ oryginałem; także miejsce i datę wydania dzieł zapisano w wersji oryginalnej. Noty katalogowe wzbogacają informacje o drukarzu i autorze księgi pod kątem ich znaczenia w dziejach książki i kultury. Omawiana jest również szata zewnętrzna książki (rodzaje czcionek, elementy porządkujące, jak kustosze, żywa pagina itd., kolofon, inicjały oraz ilustracje). Uwagi autorów nie umknął układ treści omawianych dzieł (m.in. przedmowy i regestry), których tytuły „cytowane są nieraz" ${ }^{2} \mathrm{w}$ oryginalnym brzmieniu. Charakterystykę dzieł kończy każdorazowo opis oprawy, stan zachowania woluminu, wpisy i inne znaki własnościowe (pieczątki, ekslibrisy

2 Tamże. 
i superekslibrisy) oraz wszelkie notatki w obrębie bloku książkowego i wyklejek.

W sumie czytelnik otrzymuje informacje, które swą objętością i zakresem znacznie wykraczają poza standardy bibliotecznych katalogów. Na szczególne wyróżnienie zasługuje wzbogacenie książki aż osiemdziesięcioma barwnymi ilustracjami (nie licząc zdjęcia na okładce i obwolucie), z których pięćdziesiąt jeden zajmuje całą stronę. Przedstawiają one zarówno stronice tytułowe, jak i inne karty z wnętrza książek, wybrane pod kątem urody typografii, ilustracji oraz inkunabułowych iluminacji. Dzięki temu stanowią one rodzaj przeglądu znaczących dokonań na polu typografii, grafiki książkowej i iluminatorstwa. Zestawienie ilustracji z tekstem - zamiast skupienia ich na końcu książki - wydatnie ułatwia zobrazowanie omawianych problemów.

Z wyszczególnionych cech wyłaniałby się zatem obraz wydawnictwa o wysokiej wartości merytorycznej i estetycznej. Za sprawą połączenia not katalogowych i rozbudowanych wątków historyczno-biograficznych z licznymi fotografiami zdawałoby się ono spełniać kryteria wydawnictwa stricte naukowego, jak i popularyzatorskiego. Niestety, dokładniejsza analiza treści książki wykazuje szereg niedociągnięć, niekonsekwencji i błędów, które wyraźnie obniżają jej wartość.

Pierwsze zastrzeżenia wywołuje już konstrukcja treści katalogu. Składa się on bowiem z dwóch zasadniczych części: Inkunabuły oraz Książka renesansowa. 0 ile owo rozgraniczenie stylowe zamiast czysto chronologicznego nie budzi żadnych wątpliwości przy analizie inkunabułów niemieckich i szwajcarskich, to w przypadku druków włoskich jest zwyczajnym błędem. Truizmem bowiem byłoby podkreślanie, że druga połowa XV w. w Italii była okresem szczytowego rozwoju kultury renesansowej. Przejawiało się to także w druku książek operujących antykwową czcionką i nowym stylem ilustracji drzeworytowych, nie mówiąc o preferencjach tematycznych tamtejszych impresorów (zob. poz. 9 katalogu - dzieło Boecjusza; poz. 10 - dzieło Cycerona; poz. 11 - dzieło Siliusza Italicusa itd.). Z tego punktu widzenia uzasadniony byłby jasny podział na książkę inkunabułową XV w. oraz książkę XVI w.

Podział części katalogu dotyczącej książki renesansowej (rozumianej przez autorów jako książka XVI-wieczna) jest dokonany według krajów z wyszczególnieniem największych miejskich ośrodków drukarstwa. 0 ile jednak w przypadku Francji, Szwajcarii, Niemiec i Niderlandów tytuły rozdziałów odnoszą się do poszczególnych miast, o tyle względem Italii ograniczono się do brzmienia tytułu Drukarze włoscy. Wątpliwości może też budzić włączenie Genewy do środka rozdziału poświęconego drukom francuskim (Paryż, Genewa, Lyon), skoro Bazylea - jako drugie $\mathrm{z}$ wielkich miast Związku Szwajcarskiego - trafiła jako jedyna do kolejnego rozdziału. Niewątpliwie autorzy katalogu kierowali się tutaj faktem funkcjonowania w Pa- 
ryżu i Genewie drukarskiego rodu Estienne. Zasadniejsze byłoby jednak potraktowanie Genewy jako klamry spajającej rozdziały poświęcone Francji oraz Szwajcarii, poprzez ulokowanie jej na końcu pierwszego z nich. Także brzmienie ostatniego rozdziału $\mathrm{An}$ twerpia - Officina Plantiniana wydaje się niepotrzebnie rozbudowane. W przypadku bowiem Wenecji, której we wcześniejszym rozdziale poświęcono nie mniej uwagi, zrezygnowano z wyeksponowania w tytule jej ogromnego znaczenia dla europejskiego drukarstwa. Słuszne jest zaś opatrzenie ostatniego rozdziału omawianej części katalogu tytułem Drukarze w Polsce, wiadomy jest bowiem fakt niepolskiego pochodzenia większości impresorów epoki odrodzenia.

Niekonsekwencję autorów zdradza kolejność omówień druków w obrębie rozdziałów. Nie zastosowano w nich bowiem ani układu chronologicznego, ani alfabetycznego. Przegląd dorobku danej oficyny rozpoczyna zasadniczo dzieło najwcześniejsze (np. weneckie aldyny - 1501; paryska oficyna Josse Bade'a - 1519; mogunckie druki Ivo Schöffera - 1548), dalej jednak układ chronologiczny jest naruszany, podporządkowany m.in. kryterium treściowemu lub formatowi dzieł. W rozdziale poświęconym drukom bazylejskim na pierwszym miejscu fragmentu dotyczącego dorobku Jana Oporina znalazło się - istotnie okazałe i szczególnie cenne z polskiej perspektywy - De origine et rebus gestis Polonorum Marcina Kromera w wydaniu z 1558 r. W dalszej kolejności opisa- no dzieło Izokratesa z 1571 r., lecz następnie Jacques'a Peletiera du Mans z 1563 r.

Interesującą koncepcją autorów książki jest wkomponowanie not katalogowych pomiędzy tekst historyczno-biograficzny oraz charakterystykę egzemplarzy. Są one zgrabnie wydzielone liniami i zaakcentowane drobniejszym fontem. Także konstrukcja not jest przejrzysta w swej kilkuczłonowości (tytuł dzieła, miejsce i data wydania, format wraz z uściślającą informacją o wysokości kart, foliacja bądź paginacja oraz $w$ wydzielonej strefie bibliografia i sygnatura). Szkoda tylko, że w wyartykułowanym we Wstępie założeniu rozwijania skrótów znalazły się luki, np. na s. 68 pod pozycją 33 kryje się „Henricus Stephanus”, a pod pozycją 34 „Henr. Stephanus”.

Tekst katalogu jest pisany barwnie i komunikatywnie; jego bezsprzecznym walorem są wątki historyczno-biograficzne, które znacząco uatrakcyjniają lekturę. Niestety, w sferze merytorycznej odznacza się on licznymi brakami. Najsilniej rzucają się w oczy te, które związane są z terminologią bibliologiczną. Wobec katalogowego, a tym samym fachowego, statusu wydawnictwa rażące są kolokwializmy dotyczące kwestii paleo- i neograficznych. Najjaskrawszy z nich to określenie „drukowana gotykiem”, co odnosi się do różnorakich gatunków typograficznego pisma inkunabułowego (m.in. s. $15,30,63,96,111$ ). Wyjątek czyniony jest $\mathrm{w}$ tym zakresie jedynie $\mathrm{w}$ przypadku rotundy, przy czym określenie "gotycka rotunda" wydaje się niepo- 
trzebnie rozbudowane wobec oczywistej gotyckości tego gatunku pisma (np. s. 23, 49). Skłonność autorów do uproszczeń terminologicznych ujawnia się, ilekroć w grę wchodzi pismo mniej typowe: „uproszczony gotyk” na s. 27 oraz „czerwony gotyk” na s. 62. Od nieprecyzyjności nie są wolne określenia tyczące się pisma renesansowego. We wprowadzeniu do części pt. Książka renesansowa autorzy piszą o ustaleniu się w XVI w. m.in. „pisma gotyckiego: okrągłej szwabachy i ostro łamanej fraktury". Abstrahując od oczywistej sprzeczności zawartej w stwierdzeniu o ustaleniu się form gotyckich $\mathrm{w}$ renesansie, należy podkreślić, że szwabasze daleko jest do „okrągłej” formy, wyróżnikiem zaś fraktury - także na tle szwabachy - jest nie tyle ostre łamanie trzonków literowych, ile finezyjna dekoracyjność. Dostrzegalne są również kłopoty autorów z ujęciem relacji między antykwą i italiką (kursywą): na s. 45 pada bowiem stwierdzenie „antykwa prosta i kursywa”. Należy też podkreślić, że antykwa nie jest „stylem” (s. 26), ale gatunkiem (typem/odmianą) pisma funkcjonującym od epoki renesansu.

Trudne do zaakceptowania w wydawnictwie bibliologicznym są udziwnione zamienniki pojęć dawno ustalonych i przyjętych w rodzimej terminologii fachowej. Odnosi się to do „litery każdego zdania w tekście [, którą] przekreślono czerwoną kreseczką", czyli rubryki (s. 13), „czerwonej skórki" na grzbiecie książki - czyli szyldzika (np. s. 65), czy też konsekwentnie stosowanego „cięcia” zamiast obcię- cia bloku książki (np. s. 57). Niejasno brzmi też zdanie tyczące się kobergerowskiego druku z 1496 r.: „Brak pierwszej karty, pustej lub zawierającej jakiś element tytułu".

Wobec powyższego nie dziwi pojawienie się szeregu drobnych błędów lub nieprecyzyjności terminologicznych ze sfery pozabibliologicznej, w tym zwłaszcza historyczno-artystycznej. Autorom należy zarzucić przede wszystkim nieostrożne posługiwanie się pojęciami, które mają swoje zawężone znaczenie lub ramy chronologiczne. Nas. 57 mowa jest o druku rzymskim z 1585 r., w którym współczesną mu frontyspisową grafikę wykonano rzekomo „W stylu renesansu włoskiego"; w rzeczywistości renesans jako styl w sztuce zdążył ustąpić we Włoszech już w pierwszej połowie XVI w., wyparty przez manieryzm. Ostatnia ćwierć XVI w. wiąże się zaś w Italii ze stopniowym upowszechnieniem kolejnego stylu - baroku; jego centrum był wówczas właśnie Rzym. Dowodem lekceważenia zasadniczych różnic między klasycznymi technikami graficznymi jest stwierdzenie: „na tablicach miedziorytowych (akwafortowych)". Nie zaskakuje wobec tego pomyłka, która wkradła się do podpisu pod ilustracją na s. 47: ukazano na niej odbitkę nie miedziorytniczą, ale akwafortową. Korekcie należy poddać też kilka drobniejszych błędów: zamiast określenia profesji Francesca Griffa jako „snycerz-liternik” winno być rytownik-liternik; w tym przypadku autorów może jednak usprawiedliwiać powtórzenie błędu za ha- 
słem w Encyklopedii wiedzy o książce ${ }^{3}$. Słowo „kartusz” na s. 76 winno być zastąpione po prostu tarczą herbową (o ozdobnym kształcie); inicjały Josta Ammana - „J.A." - zostały błędnie odczytane m.in. z drzeworytu, którego fotografia widnieje na s. 106 (autorów zapewne zwiódł dekoracyjny krój litery „A” przecinającej „I”); dyskusyjne jest określenie broni w ręku wojownika ze strony tytułowej Sarmatiae Europeae Aleksandra Gwagnina w wydaniu spirskim z $1581 \mathrm{r}$. jako „buława” (s. 108), jej kształt wskazuje, że jest to raczej buzdygan w typie węgierskim. Wizerunki władców, które są wzmiankowane na s. 108, nie są „symboliczne", tylko imaginacyjne; równie zasadne byłoby zresztą określenie ich jako „wyobrażenia władców”. Uproszczeniem cechuje się określenie motywu z ilustracji na s. 136 jako „arkada”; biorąc pod uwagę jego architektoniczną podstawę oraz półkoliste zwieńczenie $\mathrm{z}$ dekoracją $\mathrm{w}$ tympanonie i motywami puttów po bokach, zasadniejsze byłoby sformułowanie: arkadowe obramienie okienne lub ołtarzowe. Do polemiki skłania też sąd o drzeworytach druku zreprodukowanego na s. 111, „dobrze świadczących o umiejętnościach ich autora". W rzeczywistości - jeśli za punkt odniesienia wziąć

${ }^{3}$ Zob. Griffo Francesco, [w:] Encyklopedia wiedzy o książce, pod red. A. Birkenmajera, B. Kocowskiego, J. Trzynadlowskiego, Wrocław-Warszawa-Kraków 1971, sz. 831-832. Snycerzem jest artysta rzeźbiący $\mathrm{w}$ drewnie. Por. Snycerstwo, [w:] Słownik terminologiczny sztuk pięknych, pod red. K. Kubalskiej-Sulkiewicz, M. Bielskiej-Łach, A. Manteuffel-Szaroty, Warszawa 1996, s. 384. choćby ilustracje różnych drzeworytów XVI-wiecznych z innych stron katalogu (np. s. 113, 119, 106) - rycina ta odznacza się bardzo przeciętnym poziomem wykonawstwa. W końcu skorygowania wymaga identyfikacja instrumentów z ilustracji na s. 59; ukazane są tam nie „fisharmonia i gitara”, ale organy i lutnia. Zabawnie w świetle współczesnej zoologii brzmi też określenie „zwierzęta i ptaki” (s. 91), które winno być zastąpione pojemnym określeniem „motywy zoomorficzne”.

Obok błędów merytorycznych o różnym ciężarze gatunkowym w tekście występują także literówki, np. „zagranicznych" zamiast zagranicznym (s. 129), ,Penzer” zamiast Panzer (m.in. s. 40, 174). Nieprawidłowe jest też ujednolicanie kwadratowych nawiasów uzupełnień abrewiatur z otaczającym tekstem kursywnym (np. s. 34, 36). Trzeba jednak przyznać, że potknięcia tego typu są bardzo nieliczne, co świadczy o rzetelnym opracowaniu redakcyjnym książki.

Bezbłędnie wykonanym fotografiom katalogowym towarzyszą każdorazowo podpisy. Treść podpisów pod nimi sprowadza się do numeru pozycji katalogowej, nazwiska i imienia (lub jego inicjału) autora, skróconego tytułu, miejsca i daty wydania. Ostatnim członem podpisu są zwięzłe hasła dotyczące najciekawszego - w odczuciu autorów - składnika reprodukowanej stronicy. Takowe są jednak zazwyczaj drobnym fragmentem całości, co może dezorientować nieobeznanego czytelnika. I tak np. pod zdjęciem całej karty inkunabułu z tekstem w typie modus 
modernus czytamy wyłącznie o „inicjałach drzeworytowych" (il. na s. 24); raz karta z iluminowanym inicjałem i floraturą marginalną jest opatrzona podpisem, który dotyczy obu (il. na s. 18), raz tylko inicjału (il. na s. 22). Podpis pod ilustracją urodziwej - całej - karty renesansowego inkunabułu włoskiego o antykwowej czcionce i dawnych zapiskach marginalnych nakierowuje uwagę czytelnika jedynie na „reprezentanta inicjału” (il. na s. 35). Zastrzeżenia w podobnym duchu tyczą się wielu innych reprodukcji. W innych przypadkach pożądane byłoby doprecyzowanie sformułowań: „charakterystyczny układ tytułu" na ilustracji ze s. 52 to układ półklepsydrowy; „kolorowy drzeworyt: inicjał $M$ " to po prostu „czerwony inicjał drzeworytowy” (il. na s. 53); na ilustracji ze s. 135 są ukazane trzy - a nie jeden - drzeworyty; na il. ze str. 148 wbrew podpisowi („kolorowy inicjał drzeworytowy”) widnieje inicjał odbity czarną farbą.

Wśród obfitości fotografii całych stron i ich fragmentów zastanawiający jest brak choćby jednej, która przedstawiałaby oprawę. Dziwi to wobec potencjalnej wartości estetycznej przynajmniej kilku z nich, co sygnalizują opisy. Niewykluczone zresztą, że w zespole opraw z uniwersyteckiej biblioteki znajdują się obiekty, których ranga historyczna i artystyczna przewyższa chronione przez nie druki. Niestety, z opisów rzeczonych obiektów nie sposób się tego dowiedzieć.

Na tym większą uwagę zasługują więc informacje o znakach własnościowych, którymi opatrzono druki. Auto- rzy wymieniają wśród nich zarówno pieczątki, typowy graficzny ekslibris, jak i superekslibrisy różnych typów.

Superekslibrisy herbowe są reprezentowane przez dwa dzieła. I tak, na s. 68 jest wzmiankowana „plakietka z herbem (superekslibris?)". Lapidarna informacja utrudnia bliższe określenie formy i funkcji tego wycisku; być może chodzi tu o przykład superekslibrisu ślepo wyciskanego z prostokątnej plakiety. Takowa forma znaku własnościowego znamionowała introligatorstwo kręgu niemieckiego, w tym także środowisko gdańskie. Niewykluczone jednak, że kryjący się pod opisem herb nie spełniał funkcji oznaczania własności książki, a stanowił znak poddaństwa właściciela introligatorni oraz właściciela księgi wobec lokalnego władcy (np. księcia pomorskiego lub elektora saskiego). Rozstrzygnięcie tej kwestii byłoby możliwe po dokładnym oglądzie wycisku dzieła. Niewątpliwym superekslibrisem herbowym jest zaś dzieło wykonane dla Stanisława Górskiego herbu Bogoria (s. 125). Obiekt ten odznacza się odosobnionym $\mathrm{w}$ polskich warunkach sposobem przedstawienia godła herbowego ${ }^{4}$. Zgodnie z terminologią heraldyczną są to dwa żeleźca w słup połączone ze sobą; po ich bokach wyciśnięto inicjały „S[tanislaus] G[orski/órski] | C[anonicus] C[racoviensis]", całość zaś

${ }^{4}$ Oprawy polskie. Wystawa zorganizowana przez Bibliotekę Narodowa i Oddział Warszawski Towarzystwa Przyjaciół Książki, komisarz wystawy i red. katalogu A. Żółtowski, Warszawa 1987, s. 14, tabl. 4; K. Rulka, Superekslibrisy w zbiorach Biblioteki Seminarium Duchownego we Włocław$k u$, „Studia Włocławskie” 2003, t. 6, s. 533. 
jest otoczona okrągłym pierścieniem z perełkowaniem. Dokonany przez autorów katalogu opis oprawy sygnalizuje, że może to być przykład wyrobu krakowskiej introligatorni działającej około połowy XVI w.

Wymienione w katalogu dwa superekslibrisy inicjałowe występujące bez herbu bądź innego motywu identyfikującego właściciela księgi (s. 99, 114) były typowe dla niemieckiego kręgu kulturowego.

Superekslibris napisowy, który opisano na s. 118, należał zaś do Piotra z Poznania (ok. 1500-1579), profesora Uniwersytetu Krakowskiego, lekarza nadwornego Zygmunta Augusta, biblisty i kanonika ${ }^{5}$. Godne rozwinięcia jest słuszne spostrzeżenie autorów o nieprawidłowej kolejności wyciśnięcia tłoków literowych na oprawie z jego księgozbioru. Podobne przypadki są relatywnie często spotykane w ówczesnych oprawach, zarówno w superekslibrisach, jak i tytułach dzieł i nazwiskach ich autorów. Występowały one obok błędnych wycisków plakiet dekoracyjnych i superekslibrisów (nawet ich odwrotnego wyciśnięcia względem reszty dekoracji!) oraz pozostałych narzędzi introligatorskich. Nierzadkie były też wyciski narzędzi zbyt gorących, wręcz wypalających skórę, co świadczy o pośpiechu, niezdarności i niedbałości, z którymi niekiedy oprawiano druki w ówczesnych pracowniach.

${ }^{5}$ Piotr z Poznania, [w:] Wielkopolski słownik biograficzny, kom. red. przewod. A. Gąsiorowski i J. Topolski, Warszawa-Poznań 1981, s. $570-571$.
Pisząc o przejawach obniżania jakości estetycznej książki w sferze introligatorskiej, wypadałoby odnieść ten problem do całych ksiąg z bydgoskiej książnicy. Z opisów i fotografii zamieszczonych w katalogu jasno bowiem wynika, że stan zachowania niektórych $\mathrm{z}$ nich jest niezadowalający. Na zreprodukowanych kartach ujawniają się niekiedy obszerne zalania i zabrudzenia (np. il. na s. 42,130), ślady po żerowaniu owadów (il. na s. 32,44 ) i ubytki fragmentów kart (il. na s. 22, 130); w opisach bywa też mowa o ubytkach całych kart, a nawet wymiernego procentu objętości książek. Niestety, nie jest to zjawisko odosobnione w polskich realiach, w czym ujawnia się dramatyzm losów zabytkowych księgozbiorów na ziemiach Rzeczypospolitej. Niektóre księgi noszą również ślady barbarzyńskich praktyk pseudokolekcjonerskich. Bodaj najdrastyczniejszym przykładem jest tu słownik łacińsko-dziesięciojęzyczny Ambrożego Calepinusa, wydany w Bazylei u Sebastiana Henricpetra w 1590 r. (s. 93). Książce tej brakuje czterech pierwszych stron oraz dziewiętnastu wyciętych inicjałów. Uszkodzenia te muszą przesądzić o zakwalifikowaniu woluminu do destruktów. To z kolei rodzi pytanie o zasadność włączenia tego dzieła do kategorii cimeliów. Pytanie tym zasadniejsze, że zarówno tematyka, jak i metryka druku wskazują na jego popularność oraz wysoki nakład.

Do pytania o słuszność wyboru skłania też szereg innych dzieł. Jednym z nich jest pozycja $\mathrm{nr} 69$ katalogu Opera D. Aurelii Augustini Hipponensis epi- 
scopi, continens sermones ad populvm et clerum, $\mathrm{w}$ antwerpskim wydaniu Krzysztofa Plantina z 1576 r. ${ }^{6}$ Wolumin $\mathrm{z}$ bydgoskiej biblioteki to zaledwie jeden - dziesiąty - tom z dziesięciotomowego wydania. Dzieła św. Augustyna to jedna z kanonicznych publikacji Kościoła katolickiego, drukowana w olbrzymich - jak na nowożytne warunki - nakładach na potrzeby m.in. rozrastającego się aparatu kościelno-klasztornego. Nieprzypadkowe zatem było podejmowanie się druku tych wydawnictw przez największe i najprężniejsze europejskie oficyny, jak właśnie plantinowska. Znajdują się one do dziś w licznych bibliotekach krajowych, nie wspominając o europejskich i amerykańskich - zarówno kościelnych, jak i świeckich, co obdziera je z aury wyjątkowości i nadzwyczajnej wartości. Fakt wydrukowania dzieła u sławnego impresora okazuje się zatem zbyt słabym czynnikiem, by włączyć je do kategorii cimeliów.

Być może więc należało zmienić - a przynajmniej rozszerzyć - kryteria wyboru książek do katalogu? 0 ich szczególnej, tytułowo cimeliowej wartości może przesądzić bowiem nie tylko fakt wydrukowania w słynnej, wielopokoleniowej oficynie $\mathrm{z}$ dużego ośrodka miejskiego, ale i przeciwnie w oficynie mało znanej, z małej miejscowości, produkującej w małych nakładach i przez krótki czas. Zaliczenie

${ }^{6}$ W katalogowej części kanonicznej monografii oficyny Plantina autorstwa L. Degeorge publikacja ta figuruje wśród czternastu innych druków, które wyszły z oficyny w 1577 r., w okresie jej głębokiego kryzysu. Zob. L. Degeorge, La maison Plantin a Anvers, Paris 1886, s. 174. do cimeliów ksiąg dawnych, reprezentujących np. nauki ścisłe, przyrodnicze, medyczne tudzież tajemne, jest dziś oczywiste. Jednak i wśród prac religijnych drukowanych na Zachodzie znajdują się takie, które z rodzimej perspektywy przesądzają o ich szczególnej wartości: dzieła dedykowane Polakom. Wprost doskonałym kryterium cimeliowości są dostojne proweniencje „wielkich tego świata” lub choćby lokalnego, polsko-litewskiego światka. W omawianym katalogu ani razu nie zostały one należycie wyeksponowane. Jeśli przyjąć, że w bydgoskiej książnicy nie znajduje się żadne dzieło pochodzące z kręgów europejskiej arystokracji lub rodzimej magnaterii i hierarchów kościelnych, to skłaniał do tego choćby wspominany Stanisław Górski, a konkretniej jego osobliwy superekslibris. Także i oprawa - piękna, kosztowna, oryginalna formalnie bądź ze słynnego warsztatu zachęca do odpowiedniego wyróżnienia. Wśród kilkuset ksiąg XV-XVI w., które są zgromadzone $\mathrm{w}$ bydgoskiej bibliotece uniwersyteckiej, niewątpliwie są przechowywane dzieła introligatorstwa nie mniej zasługujące na uwagę niż bądź co bądź masowe wydawnictwa Kobergera i Plantina.

Jak zatem - wobec powyższej analizy - ocenić dokonanie bydgoskich bibliologów?

Godnym pochwały przedsięwzięciem jest samo opublikowanie książki, która w założeniu łączy cechy fachowego katalogu i wydawnictwa popularnonaukowego o charakterze quasi-albumowym. Wypełnienie jej notami 
bibliograficznymi, jak również obfitymi wątkami historycznymi, a nawet anegdotycznymi sprawia, że książka taka jest potencjalnie atrakcyjna zarówno dla specjalisty, jak i hobbysty bibliofila. Przystępna, a zarazem barwnie pisana treść książki mogłaby też przesądzić o jej sporej wartości dla studentów bibliologii czy historii i historii sztuki.

Dzieje się tak mimo zderzenia się autorów z przeszkodą obiektywnej natury. Jest nią faktyczna skromność zasobów bydgoskiej biblioteki, która nie pozwala na zobrazowanie szeregu istotnych problemów XVi XVI-wiecznej książki europejskiej. To zaś już przy pobieżnym oglądzie pracy rodzi pytanie, czy zasadniejsze nie byłoby nadanie jej tytułu „Inkunabuły i [po prostu] wybrane druki XVI wieku w zbiorach [...]". Biorąc bowiem pod uwagę przebogaty dorobek drukarstwa, ilustratorstwa i introligatorstwa obu stuleci, okazuje się, że to, co czytelnik dostrzega na kartach kata-

Pubir ublikacja pt. Od książki dawnej do biblioteki wirtualnej pod redakcją Doroty Degen i Małgorzaty Fedorowicz została wydana przez Wydawnictwo Naukowe Uniwersytetu Mikołaja Kopernika w Toruniu w 2009 r. Stanowi ona zbiór referatów, jakie zostały wygłoszone w dniach 23-24 października 2007 r. na ogólnopolskiej konferencji naukowej zatytułowanej „Od książki dawnej do biblioteki wirtualnej przeobrażenia bibliologii polskiej. $\mathrm{Na}$ marginesie trzydziestolecia Instytutu logu, jest nad wyraz skromne, w niektórych przypadkach wręcz dyskwalifikujące z kategorii cimeliów w wymiarze nie tylko światowym, ale nawet polskim.

O ile jednak pojęciowe dowartościowanie zbiorów Biblioteki Uniwersytetu w Bydgoszczy można wytłumaczyć działaniem marketingowym uczelni, o tyle trudne do usprawiedliwienia są błędy, niedociągnięcia i nieścisłości w konstrukcji i treści książki. Ich obfitość i konsekwencja, z jaką są popełniane, sprawiają, że dzieło wiele traci ze swej fundamentalnej wartości, a jest nią wartość poznawcza.

To zaś musi przesądzić o krytycznej ocenie książki jako wydawnictwa o interesujących założeniach formalno-treściowych, ale niedbałym opracowaniu merytorycznym.

\section{Arkadiusz Wagner}

Instytut Informacji Naukowej i Bibliologii Uniwersytetu Mikołaja Kopernika w Toruniu

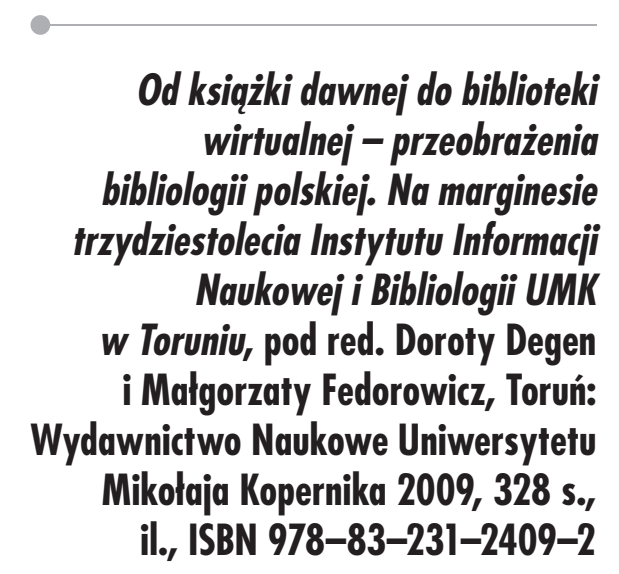

